\title{
新規表面サイズプレス用澱粉についで*
}

\author{
王子コーンスターチ株式会社 技術本部開発研究所 石 由 光 雄
}

\section{New Modified Starch for Surface Size Press}

\section{Mitsuo Ishida}

Research and Development Laboratory. Oji Cornstarch Co.. Ltd.

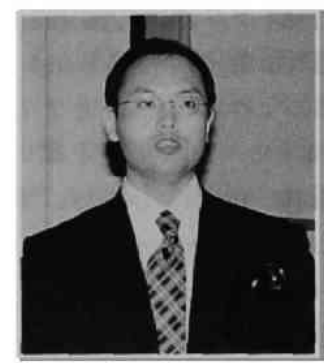

This Paper presents new modified starch for surface size press, which improves vessel pick trouble on newspaper printing. We solved its problem by developing new type oxidized starch with much aldehyde group, which also improved surface tackiness on offset printing.

分類： $\mathrm{W}_{5}$ 紙力増強㓮, $\mathrm{S}_{3}$ 新閶巻取紙

\section{1.はじめに}

新闒用紙への古紙の配合比率は以前から增加しつつ あるが，特に，最近は環境問題からの社会的要請もあ って，古紙多配合化傾向が一简高まっている。また， 古紙配合割合が増えていくのと同時に，新闒紙の軽量 化も進んでおり，1990年代には坪量 $43 \mathrm{~g}$ であった が, 2001 年には $40 \mathrm{~g}$ という超軽量化の新聞紙が現れ る赘いで変化している。この様な縓しい条件の上に， オフセット印刷の普及による印刷の高速化や多色印刷 化の增加傾向もあって，新聞紙への品質要求は高まっ ていく一方である。

以前は，新聞紙に紙力增强を目的とする製紙用楽品 は殆ど使用されていなかったが、湿し水を付けるオフ セット印刷の普及により内添紙力增强剤が多く使用さ れるようになった。更に，印刷の高速化に伴い，抄紙 の高速化や印刷時の紙粉防止のため, ゲートロールコ ータにより㳀粉系表面サイスプレスを使用することが 圭流になった。

このゲートロールコータ塗エのための表面サイズ用

・平成 12 年度年次大会講演（講演 No. B 10）
糊剂も様々に検討されて，オフセット印刷の高速化, 多色印刷化という婇しい条件に対応してきたが，新開 紙の古紙多配合化と軽量化によりオフセット印刷時の 古紙由来によるベッセル剥離が秘念されるようになり， その対策が必要とされるようになってきている。そこ で幣社では表面サイズプレスによってベッセルピック を抑制することを考え，新規の表面サイズプレス用㳶 粉「乾式酸化般粉」を開発したので, 開発の概要とそ の効果について速べる。

\section{2. ベッセルピックへの対応}

ベッセルは他の紻維に比べて非常に大きく，図1の ように表面に存在している場合は紙中の他の繒維上に 浮いているような感じである。よって，他の樴維に比 ベて容易に剥離し易い。このベッセルを表面サイズブ レスで固定化させる方法の一つには，表面に留まりや すい糊剂を多く渒工し、ベッセル表面全体を覆うこと である（図 1-a）。もう一つの方法としては，浸透し 易い糊剂を用いてベッセルの根本をしっかりと固めて 固定化する方法である(図 1-b)。

（図 1-a）の方法では表面强度は確かに向上するが, オフセット印刷時の湿し水によるネッパリが新たな問 


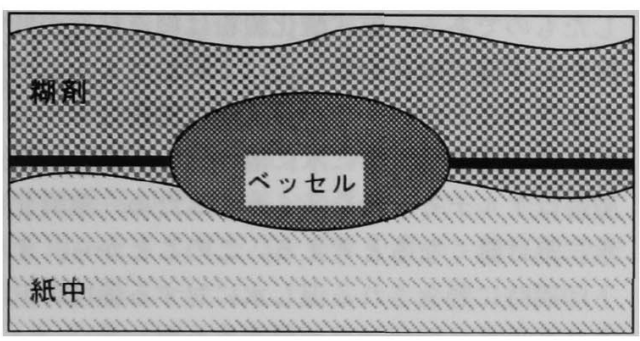

图 1 - $\mathrm{a}$ 表面被膜

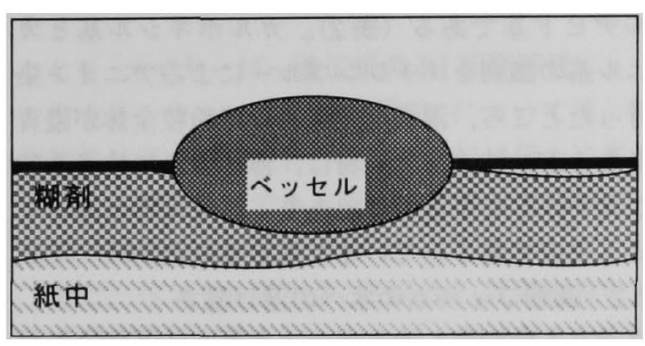

図 1-b 浸透固定

図 1 ベッセルピック対策

題になる可能性が大きい。

また（闵 1-b) の方法では，一般に糊剂の粘度を下 げなければならない。糊郕の粘度を下げる方法として は主に分子量を小さくするのが普通であるが，低分子 化を行うと表面強度が弱くなるという久点が生じる。 更に低分子化することにより表面サイズ刻として使用 した際，水に対して溶出し易くなる：このため，オフ セット印刷時の湿し水による表面強度の低下、ネッパ リの懸念が生じてくる。

そこで，（図 1-a）の方法では塗工量が多くコスト が高くなってしまうため。他の方法として（図 1-b) の考えに基づき，塗工量がそれほど多くはなく，低分 子化しても表面强度が保持でき，また，水に対しての 溶出も抑えられる新たな設粉を開発した。

\section{3. 新規表面サイズプレス㱖粉「乾式酸化澱粉」}

表面サイズブレスに用いられる糊哊としてはPAM， PVA，酸化浅粉がよく知られている。これらはどれ も表面強度を向上させることができる。しかし，糊鼡 を浸透させてべッセルピックを抑制するために婟郕の 粘度を低下させると, 表面強度の低下や水に対する溶 出量の增加は避けられない。糊液粘度を低下させても これらの欠点を克服できる新規の激粉「乾式酸化汯粉」 を開発した。

3.1 乾式酸化激粉とは

ベッセルピックを抑制するために今回幣社が開発し

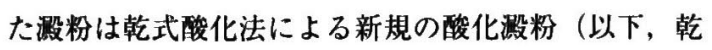
式酸化殷粉と記載)である。これは従来の酸化汯粉 (以 下, 湿式酸化汼粉と記載) とは全く製法や品質が異な る(表 1)。

この乾式酸化法によって製造した乾式酸化筂粉を表 面サイズプレスに用いた場合，粘度が低くても表面強 度が低下せず，水に対する溶出が少ないという特長を 有する。これは乾式酸化段粉がアルデヒド基を多く有 するため、アルデヒドによる架橋化により滶粉被膜が 強固なものになるためと推定している。

以下，この新規の乾式酸化激粉について，従来型の 酸化澱粉である湿式酸化測粉と比較しながら, 表面サ イズプレス用清粉としての適性について述べる

\section{2 乾式酸化激粉と湿式酸化澱粉の比較}

\subsection{1 乾式酸化澱粉の品質比較}

今回新たに開発した乾式酸化激粉と従来からある湿 式酸化澱粉の大きな違いは，酸化反応により生成した 官能基が，湿式酸化測粉は従来から知られているよう にカルボキシル基であるのに対して、「乾式酸化澱粉」

表 1 乾式, 湿式酸化澱粉の違い

\begin{tabular}{l|c|c}
\hline & 乾式酸化測粉 & 湿式酸化測粉 \\
\hline 反応方式 & 乾式焙焼反応 & 水系スラリー反応 \\
\hline 主な生成官能基 & アルデヒド基 & カルボキシル基 \\
\hline
\end{tabular}

表 2 乾式, 湿式酸化澱粉の品質比較

\begin{tabular}{l|c|c}
\hline & 乾式酸化敗粉 & 湿式酸化澱粉 \\
\hline $\mathrm{B}$ 型粘度 $\left(50^{\circ} \mathrm{C}, 15 \%\right)$ & $15 \mathrm{mPa} \cdot \mathrm{s}$ & $25 \mathrm{mPa} \cdot \mathrm{s}$ \\
\hline アニオン染色 (カルボキシル基) & 殆どなし & 有り \\
\hline アルデビド基量 & $0.31 \%$ & $0.01 \%$ \\
\hline 澱粉フィルム溶出率 & $30 \mathrm{w} / \mathrm{w} \%$ & $55 \mathrm{w} / \mathrm{w} \%$ \\
\hline
\end{tabular}


はアルデヒド基である（表2)。カルボキシル基とカ ルボニル基の識別をメチレンフルーによるアニオン染 色で行ったところ，湿式酸化海粉は澱粉粒全体が濃青 色に染まるが, 乾式酸化洀粉は、薄い青色に染まる段 粉粒が僅かに存在するだけであり，酸化反応は殆とア ルデヒド生成で終了していると推定された。

\section{2 .2 腶粉フィルムの水への溶け易さ}

オフセット印刷湿し水に対する表面サイズ剤として の効果を想定し，水に対する泚粉フィルムの溶出率を 調べた(図2)。これは洀粉轱液を乾燥させてフィル ム状にし(以後これを「晸粉フィルムと呼ふ」), $25^{\circ} \mathrm{C}$ の水中に 30 分間浸し, 溶け出した渐粉の割合を測定

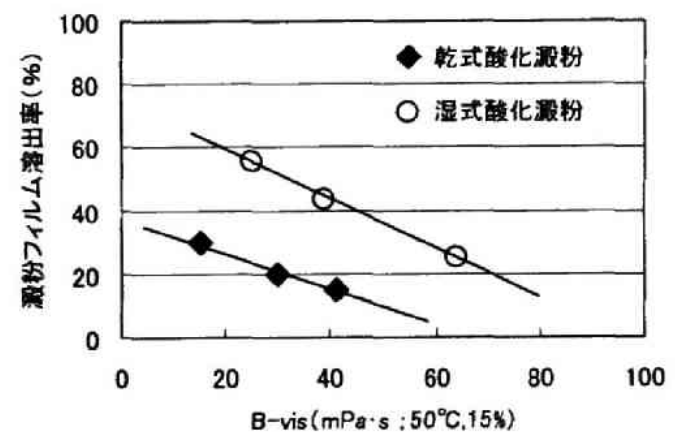

図 2 測粉フィルムの水への溶出率

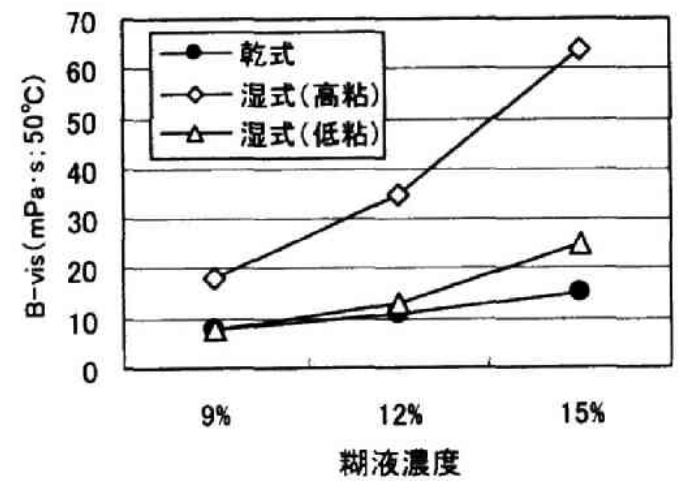

図 3 乾式, 酸化海粉 B 型粘度

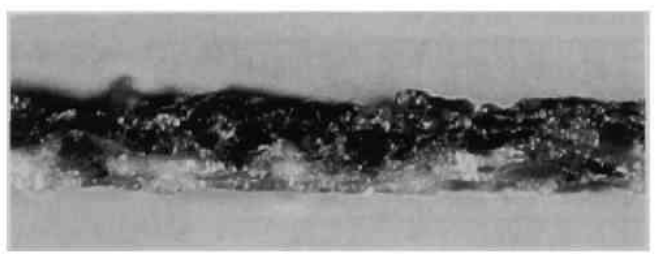

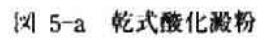

したものである。乾式酸化澱粉は糊液粘度が低いにも 関わらず湿式酸化澱粉に比へて湟粉フィルムの溶出率 が小さいことが分かる。湿式酸化洀粉はカルボキシル 基を多く有するために水に溶け易い。また，乾式酸化 沸粉はアルデヒド基を多く有するため, 架橋化により 水に溶け難くなると考える。このことから，オフセッ 卜印刷時に秝念される湿し水に対する強度の低下防止 及びネッパリ抑制効果が期待された。

\subsection{3 糊液粘度比較}

楜液粘度については，湿式酸化海粉の B 型粘度は 糊液濃度が高くなるにつれて增粘傾向が大きくなるが, 乾式酸化筑粉は增粘傾向が小さいという特長を持つ (図3)。ハイシェア粘度については, 乾式酸化殷粉は $\mathrm{B}$ 型粘度が同程度である湿式酸化激粉に比べて低いこ とが分かる(図 4)。

\section{3 紙中への糊液浸透比較}

糊液粘度が紙一の浸透に違いとして現れるかを確認 した。糊液粘度の低い乾式酸化溊粉と粘度の高い湿式

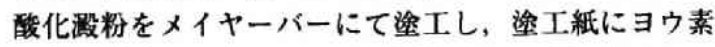
染色を施して紙断面の影微鏡写真を撮った（図 5)。 $10 \%$ 濃度の糊液を片面 $1.7 \mathrm{~g} / \mathrm{m}^{2}$ 染工したが, 粘度の 低い乾式酸化激粉（図 5-a）の方が粘度の高い湿式酸 化轺（图 5-b）よりも紙によく浸透していることが 分かる。

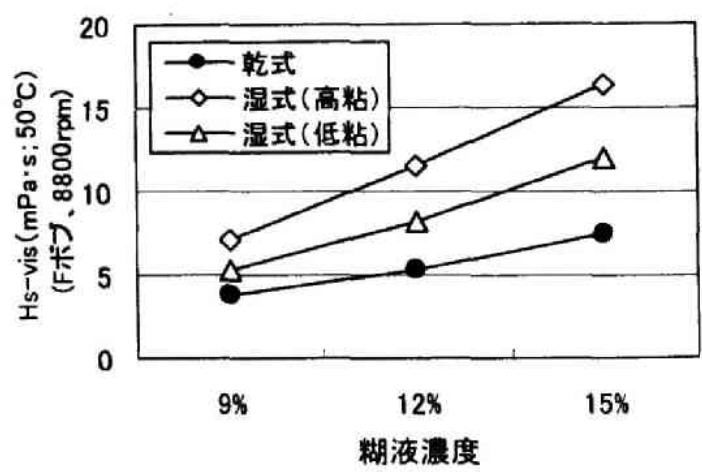

図 4 乾式, 湿式酸化波粉ハイシェア粘度

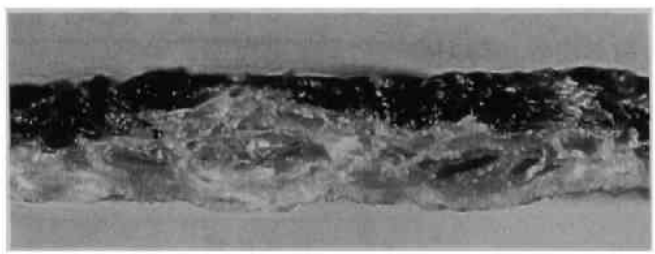

图 5-b 湿式酸化淑初

図 5 ヨウ素染色の紙断面 
4. メイヤーバー塗エによる

\section{表面サイズプレス試験}

表面サイズプレスの評価を行った。初めにベッセル の根本まで楜剤が浸透し易い条件を考虑し，希薄濃度 の糊液を用いたメイヤーバー塗工を行い，塗工紙の評 価を行った（表 3$) 。$

2〜 $4 \%$ の薄い辐液をメイヤーバーで片面塗工した 新聞紙試料を調製し，RI 印刷機を用いてドライ，ウ エット強度, ペッセルピック (白ムケ) 評価, また, 乾燥糊版のベタッキを見るネッパリ性の評価を試験し

表 3 メイヤーバー塗工条件

\begin{tabular}{l|l}
\hline \multicolumn{1}{c|}{ 原紙 } & $43 \mathrm{~g} / \mathrm{m}^{2}$ 無サイズ新聞原紙 \\
\hline 片面叙工量 & $0.2,0.4 \mathrm{~g} \mathrm{~m}^{2}$ \\
\hline 糊液濃度 & $2 \sim 4 \%$ \\
\hline 乾燥条件 & 回転式ドラムドライヤー $\left(80^{\circ} \mathrm{C}\right)$ \\
\hline カレンター後の緊度 & $0.64 \mathrm{~g}^{\prime} \mathrm{cm}^{3}$ \\
\hline
\end{tabular}

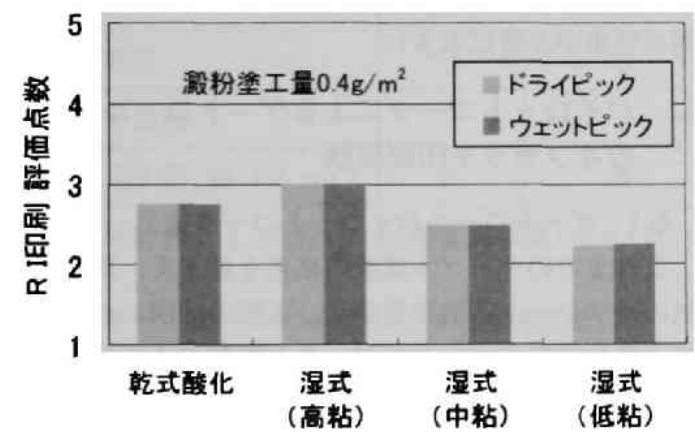

R I印刷評価: 1 (不良) < 3 (湿式高粘) $<5$ (良)

図 6 メイヤーバー塗工秖 RI 印刷表面強度

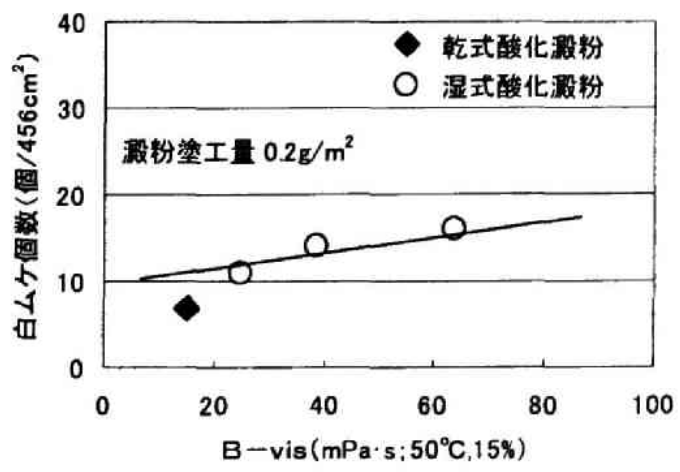

図 8 メイヤーバー粱工紙 ベッセルピックと蝴液粘度の関係
た。

4.1 メイヤーバー塗工紙の RI 印刷評価

ドライ, ウェット強度（図6）については, 乾式酸 化涠粉は湿式酸化激粉（高粘度）には僅かに劣るが， 同程度の糊液粘度である湿式酸化㳀粉（低粘度）より も良い結果であった。

また、ベッセルピック（白ムケ）評価においても， 畭式酸化翻粉が最もベッセルピック（白ムケ）が少な く、ベッセルピック抑制に効果があるものと考えられ る(図 7)。

図8は糊液粘度とベッセルピック（白ムケ）発生の 関係を示したものたが、糊液粘度が低いとベッセルピ ック (白ムケ) 発生が诚る傾向にある。この結果は, ベッセルのような大きな塊に対しては，糊液粘度が低 くてバインター能力が若干低下した糊剂でも，紙中に 浸透してベッセルの根本全体を覆って固定化させる効 果により、ベッセルピックを㧕制できることを示して いると考えられる。

\section{2 糊剤のネッパリ評価}

渐粉を沟工した紙がオフセット印刷時の湿し水によ

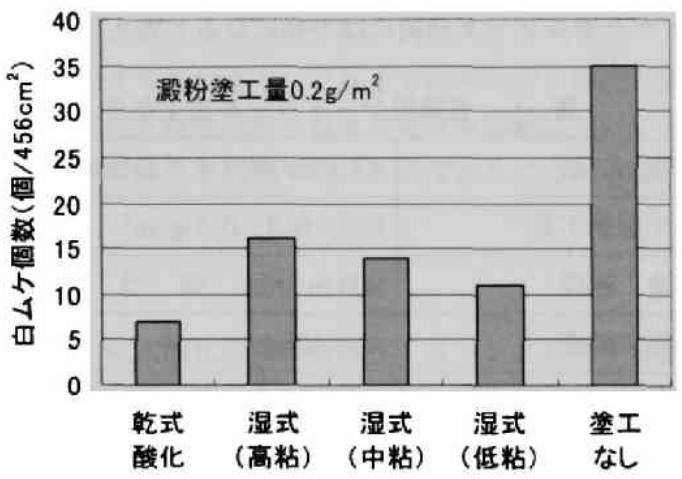

図 7 メイヤーパー染工紙 RI 印刷ベッセルピック評価

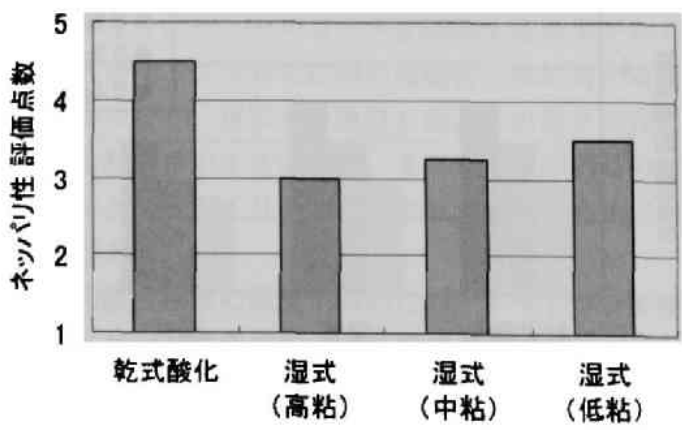

ネッパリ性評価: 1 (不良) <3(湿式高粘) $<5$ (良)

図 9 糊剂のネッパリ性評価 
って，ネッパリ性がどの程度生じ易いかを比較するた めに, 各種筑粉フィルムが水によってどの程度ネッパ リ性を生じるか, ベタッキ（ネッパリ性）の程度を相 対的に試験した（図 9)。最もペタッキ（ネッパリ性） の小さかった激粉糊剂は乾式酸化筂粉であった。ネッ パリ発生の一因としては，乾燥糊剂が水を吸収したと きの再ゾル化によって粘着性が生じるために起こると 考えられる。よって，糊剤の粘度が高いとネッパリが 起こり易いと言える。

また，乾燥糊剤の水に対する溶出が多いと再ソルル化 が促進され，ネッパリの一因となる。乾式酸化港粉が 同程度の糊液粘度である湿式酸化泚粉（低粘度）より も更に良かったのは，乾燥糊剂の水への溶出が少ない ためと考えられる。

\section{5. 実験用ゲートロール塗エによる \\ 表面サイズプレス試験}

ゲートロール染工はメイヤーバー塗工に比べて濃度 が高い糊液を塗工するため，塗工した糊凨があまり浸 透せず紙表面に多く留まり易いと考えられる。そのた め，表面強度は強くなるが浸透しやすい糊剂に較べる とベッセルピック抑制には不利になると考えられる。

表 4 実験用ゲートロール塗工条件

\begin{tabular}{l|l}
\hline 原 紙 & $43 \mathrm{~g} / \mathrm{m}^{2}$ 無サイズ新聞原紙 \\
\hline 片面塗工量 & $0.2,0.3,0.4 \mathrm{~g} \mathrm{~m}^{2}$ \\
\hline 塗工速度 & $200 \mathrm{~m} / \mathrm{min}$ \\
\hline 糊液濃度 & $8 \sim 15 \%$ \\
\hline 乾燥条件 & 回転式ドラムドライヤー $\left(80^{\circ} \mathrm{C}\right)$ \\
\hline カレンター後の緊度 & $0.62 \mathrm{~g} / \mathrm{cm}^{3}$ \\
\hline
\end{tabular}

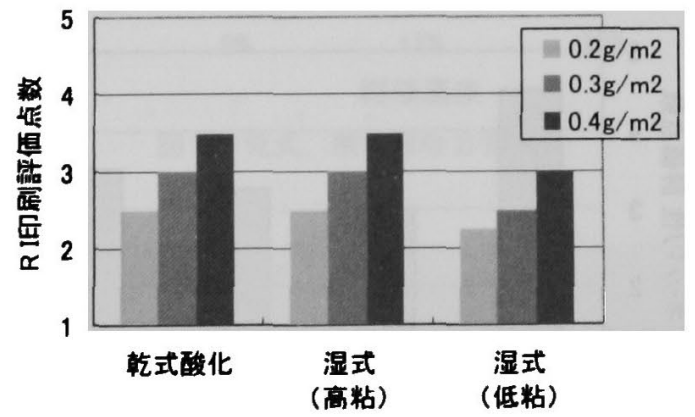

R I印刷評洒 : 1 (不良) $<3$ (湿式高粘) $<5$ (良)

図 10 実験用ゲートロール涂工紙 RI 印刷表面强度
そこで, 実験用ゲートロール塗工による試験を行っ た。新聞原紙に 8〜 $15 \%$ 濃度の糊液を用いてゲートロ 一ル塗工を行い, 回転式ドラムドライヤーで乾燥させ て新聞紙試料を調製した（表 4)。

RI 印刷表面強度試験の結果は, 乾式酸化渐粉のド ライ, ウエット強度は湿式酸化激粉（高粘度）と同等 になった（図 10）。メイヤーバー塗工では僅かに湿式 酸化澱粉 (高粘度) の方に優位性があったが, ゲート ロール塗工においては紙表面のカバーリングが良いた めか, 糊液粘度が低い乾式酸化湟粉でも表面強度が向 上した。

次に,ベッセルピック（白ムケ）評価についても， 乾式酸化激粉が最も良い結果であった（図 11）。特に 塗工量が少ない $0.2 \mathrm{~g} / \mathrm{m}^{2}$ の条件では乾式酸化澱粉と 湿式酸化筑粉のベッセルピック発生の差は大きく, 塗 工量が増加するとその差が小さくなる傾问であった。

このゲートロール塗工においても湿式酸化澱粉の例 を見ると，糊液粘度が低いと表面強度は弱くなるがべ ッセルピックを抑制する効果がある。但し, 乾式酸化 海粉は湿式酸化激粉 (低粘度) と同程度の粘度である にも関わらず表面強度は強く，更にベッセルピック抑 制の効果が非常に大きい。

6. パイロットコータによるゲートロール塗工紙 のオフセット印刷試験

\section{1 ゲートロールパイロットコータ塗工}

これまでのテーブル試験の結果を踏まえ，次に新聞 紙のオフセット印刷を実施し，実際の印刷においても 乾式酸化滶粉がペッセルピックを抑制することができ るかの評価試験を行った。

オフセット印刷を行うに当たり，ゲートロールパイ ロットコータを用いて乾式酸化澱粉, 湿式酸化筂粉(高 粘度）の塗工を行った（表 5,表 6）。

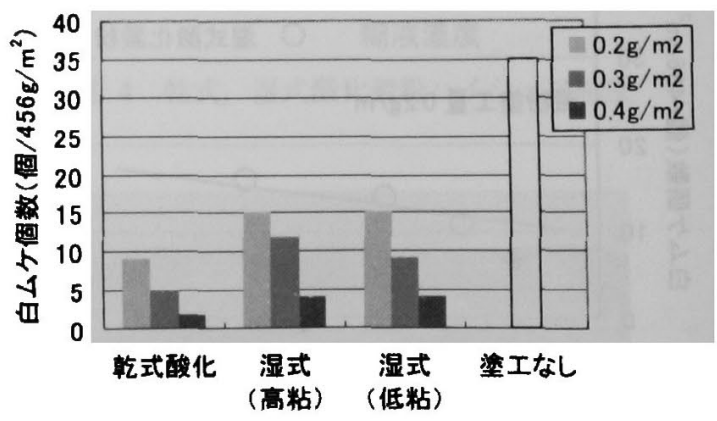

図 11 実験用ゲートロール塗工紙 RI 印刷ベッセルピック評洒 
表 5 塗工時糊液物性

\begin{tabular}{l|c|c}
\hline & $\begin{array}{c}\text { 乾式酸化 } \\
\text { 港粉 }\end{array}$ & $\begin{array}{c}\text { 湿式酸化澱粉 } \\
\text { (高粘度) }\end{array}$ \\
\hline 糊液濃度 $(\%)$ & 13.2 & 11.4 \\
\hline $\mathrm{B}$ 型粘度 $(\mathrm{mPa} \cdot \mathrm{s})$ & 43 & 188 \\
\hline ハイシェア粘度 $(\mathrm{mPa} \cdot \mathrm{s})$ & 8.4 & 14.1 \\
\hline
\end{tabular}

表 6 ゲートロールパイロットコータ塗工条件

\begin{tabular}{l|l}
\hline 原 $\quad$ 紙 & $43 \mathrm{~g} / \mathrm{m}^{2}$ 無サイズ新聞原紙 \\
\hline 片面塗工量 & $0.5 \mathrm{~g} / \mathrm{m}^{2}$ \\
\hline 塗工速度 & $400 \mathrm{~m} / \mathrm{min}$ \\
\hline 乾燥条件 & $125^{\circ} \mathrm{C}$ 熱風乾燥 \\
\hline カレンダー後の緊度 & $0.61 \mathrm{~g} / \mathrm{cm}^{3}$ \\
\hline
\end{tabular}

表 7 RI 印刷評価

\begin{tabular}{l|c|c}
\hline & $\begin{array}{c}\text { 乾式酸化 } \\
\text { 殿粉 }\end{array}$ & $\begin{array}{c}\text { 湿式酸化澱粉 } \\
\text { (高粘度) }\end{array}$ \\
\hline ドライ強度 & 3 & 3 \\
\hline ウエット強度 & 3 & 3 \\
\hline 白么ケ発生数 $\left(\right.$ 個 $\left./ 456 \mathrm{~cm}^{2}\right)$ & 16 & 26 \\
\hline
\end{tabular}

RI 印刷評価：1 (不良) $<3$ (湿式高粘度 $)<5$ (良)

\section{2 ゲートロールパイロットコータ塗工紙の RI 印刷評価}

塗工した新聞紙を先ず RI 印刷機を用いてドライ， ウェット強度, ベッセルピック（白ムケ）の評価を行 った（表 7)。これまでのテーフル試験の評価と同じ く，「乾式酸化没粉」と従来型の湿式酸化泚粉とは, ドライ,ウェット強度は同等であるが, ベッセルピッ ク（白ムケ）評洒では「乾式酸化渐粉」が湿式酸化汼 粉（高粘度）よりも優れていた。

\section{3 ゲートロールパイロットコータ塗工紙の} オフセット印刷評価

次に，オフセット印刷評価を行った（表 8,9）。印 刷部数 4,000 部目における印刷面カスレ評価は両没粉 とも良好であった。またこの時のブランケット非画 線部におけるパイリング（織維ピック）は，「乾式酸 化泚粉」の方がやや良好であった。これは糊剂ネッパ リ性の評価（図 9）の結果と一致している。

最後に, 印刷部数 3,000 部目におけるべッセルピッ ク（白ムケ）発生の数は「乾式酸化祋粉」の方が湿式
表 8 オフセット印刷評価

\begin{tabular}{l|l}
\hline ブランケット回転数 & $300 \mathrm{rpm}$ \\
\hline ドライヤー温度 & $104^{\circ} \mathrm{C}$ \\
\hline 使用インキ & TERAS-N (DIC 製) 単色刷 \\
\hline
\end{tabular}

表 9 オフセット印刷評価

\begin{tabular}{|c|c|c|}
\hline & $\begin{array}{c}\text { 乾式酸化 } \\
\text { 澱粉 }\end{array}$ & $\begin{array}{c}\text { 湿式酸化渍粉 } \\
\text { (高粘度) }\end{array}$ \\
\hline 片面塗工囬（g/m²） & 0.5 & 0.5 \\
\hline 印刷部数 & 4,000 & 4,000 \\
\hline 印刷面カスレ & 0 & $\bigcirc$ \\
\hline $\begin{array}{l}\text { ブランケットパイリング } \\
\text { (非画線部) }\end{array}$ & (2) & 0 \\
\hline ブランケット拭き取り性 & O & $\bigcirc$ \\
\hline $\begin{array}{l}\text { ベッセルピック (白ムケ) } \\
(3,000 \text { 部目印刷) }\end{array}$ & (a) & 0 \\
\hline
\end{tabular}

酸化激粉よりも少なく，これまでのテーブル評価と同 じく，「乾式酸化腶粉」はオフセット印刷においても ベッセルピックを抑制することができることが示唆さ れた。

7. まとめ

以上, 乾式酸化澱粉の表面サイズプレスに関する試 験、評価を述べてきたが，乾式酸化城粉についての特 長をまとめる。

1）アルデヒド基を多く有することで洒粉被膜の強 度や柇水性が高まる。

2）表面サイズプレスに用いた場合，表面強度の低 下がなく，ベッセルピックを抑制する効果がある。

3）表面サイスプレスに用いた場合，水に对する溶 出が少なく，更に水を吸収したときの再ゾル化に よる粘着性が小さいため，オフセット印刷時のブ ランケットパイリンクが滅少しネッパリ防止に効 果がある。

4）高濃度糊液の粘度が低いため，ゲートロール塗 エにおいて高浱度染工が可能である。

今後は,より一層新閶紙の古紙配合割合が増加する ことが予想され，同時にベッセルピックの問題も顕在 化してくるものと考えられる。その時に，この乾式酸 化澱粉が問題解決に役立つことを確信している。 


\title{
表面サイズ剤による紙の機能制御
}

\author{
ハリマ化成株式会社 制紙用菜品技術開発部 西村 紀彦
}

製紙業界の動向として古紙使用比事のアッブ，軽量化，中性化，インクジェット印刷に対応した各種 情報用紙の閶発, 内添菜品から表面薬品へのシフトが举げられる。これらは塗工蓧品が密接に関係して おり, 表面法工菜品の重要性はますます高まっている。表面登工処理は内添薬品に比べ, 歩留まりがほ ほ 100\%であること，紙表面に直接作用することで，内添での操業性の問題（抄紙機の污れ，発泡，高 温抄造でのサイズ低下）がない特徴を持っており，印刷方式の多粎化，高速化，高品犋化への缡性付加 が可能である。

本稿では，現状の問題点に対し表面サイス郕によって紙の機能制街がどのように行われているか，低 サイス紙用，新闘用、インクジェット印刷適性対応用，ネッパリ抑制機能を持った表面サイス澈を例に その技術動向について达べる。

(本文 1 ページ)

\section{エンジニアードカオリンの光学特性}

\section{イメリスピグントおよびイメリスミネラルス・ジャバン}

R. W. Wygant, R. R. lyer, D. O. Cummings, 岡川 章夫

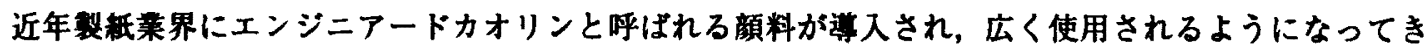
た。この願料は通常機棫的あるいは化学的に粒度分布等を改善したもので，染工層の橉造に変革をもた らすものである。超销柆子分を除去した顔料によって形成された望工層の細孔はより大きなものとなる。 この様な大きな緗孔は光敬乱奻果を高め，纸表面での液体の毛細管漫透力を抑制する役割をはたす。更 に改良された第 2 世代のエンジニアードカオリンは特に光沢の発現を改善したものである。これらの特 徽は特別に開発された紸表面の特性测定器を使って確認することができる。カオリンの最適化にはこの 測定器の開発が大きく奇与した。

(本文 8 ベージ)

\section{新規表面サイズプレス用激粉について}

\section{王子コーンスターチ株式会社 技術本部開発研究所 石田 光雄}

新閆紙はオフセット印刷の普及による印刷の高速化や多色印刷化が增加傾向にあり，また古紙多配合 化や軽量化も進行している。この様な䋛しい条件にも関わらず，印刷に対する品質要求は益々高まって いる。特に古紙多眍合化と轻量化による古紙由来のベッセルピックや表面強度を向上させるために多量 に塗工した表面サイス郕によるネッパリがオフセット印刷時に照念される。

これら新閏紙のオフセット印刷時に照念されるベッセルピック，ネッパリを抑制させるために新規の

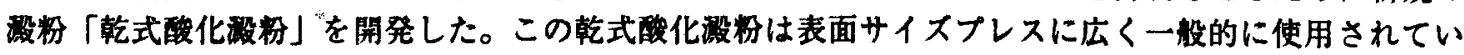

